\title{
Obrazy Polski i Polaków w Dymitriadach z perspektywy brytyjskiej
}

Beata Cieszyńska 


\section{Beata Cieszyńska}

\section{Obrazy Polski i Polaków w Dymitriadach z perspektywy brytyjskiej}

$\mathrm{R}$ ola odegrana przez Polskę oraz glośne losy Polaków zamieszanych w Dymitriady' żywo interesowaly siedemnastowiecznych Brytyjczyków. Ich perspektywa byla jednak perspektywa kraju odleglego, protestanckiego i kupieckiego, Polska reprezentowala przede wszystkim „obcego”. Patrzącym z odległości Wysp Brytyjskich autorom, nawet wtedy, gdy byli naocznymi świadkani tragicznych wydarzeń moskiewskich, umykały często szczegóły udziału przedstawicieli Rzeczypospolitej w I)ymitriadach, zróżnicowanego przecież w kolejnych ich etapach. Utrudniało to wyrobienie sobie opinii na temat stopnia reprezentatywności działań zamieszanych w Dymitriady Polaków dla ogólu obywateli. Stąd liczne ujednoznacznienia i uproszczenia w interpretacjach zarówno polskich motywacji. jak dzialań. W takiej perspektywie dla przykładı czyny Lisowczyków z łatwością mogly reprezentować postawę przeciętnego szlachcica polskiego. I Iisteryczny antykatolicyzm i antyjezuityzm, na Wyspach zbierający żniwo przez cale XVII stulecie, dodatkowo wzmacnial tendencję do uproszczeń. Jeśli do tego dodamy zagrożenie, jakie Dymitriady niosty dla handlı z Rosją, otrzymamy glówne rysy obrazu Polski i Polaków w omawianych utworach.

Zainteresowanic Dymitriadami i odegraną w nich przez Polskę rolą ujawnito się w dwu typach produkcji piśmienniczej: w relacjach brytyjskich naocznych świadków tragicznych wypadków, a więc przebywających w Moskwie kupców i żolnierzy, piszących, by „dać świadectwo", oraz w literaturze, dla której Dymitriady szybko staly się źródłem swobodnie przywoływanych i przerabianych motywów, słuzą̧cych do interpretacji (często odległych od samej historii) dziejów Brytyjczyków i Europy.

' Najpeluicjsze polskic opracowanie Dymitriad zob.: A. Andrusicwicz: Dzigje Dy'mitriad 1602-1614, t. 1: Na-

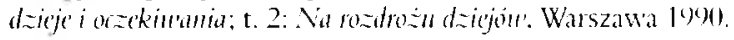


Najbogatszy zbiór brytyjskich utworów poświęconych moskiewskim wypadkom zebrany zostal w 1916 roku przez Sonię I Iowe w: The False Dnitri: a Russian Romance and Tragedy'. Utwory te stanowią interesujący zapis dramatu państwa moskiewskiego oraz przebywających na jego terenie obcokrajowców w czasie Wielkicj Smuty i uzurpacji kolcjnych Dymitrów ${ }^{3}$. Ze zbioru przygotowanego przez Sonię l lowe pochodzi znaczna część analizowanych tu utworów, uzupełnionych poennatem Locusms Fincasa Fletchera oraz antyjakobicką tragedią Mary Pix The Czar of Muscol'y'

Dla potrzeb ninicjszego artykulu brytyjskie teksty opisujące udzial Polski w Dymitriadach podzielone zostaly w oparciu o kryterium gatunkowo-celowościowe. Osobno analizowane są bezpośrednie relacje, odrębnie zaś utwory o przewadze cech literackich. Kryterium to nie jest oczywiścic niczawodıc. Miçdzy tak zarysowanymi biegunami napotkamy relację naocznego świadka Dymitriad (podpisanego ,J. F."): A Brief Historical Relation of the Empire of Rusia, z roku 16.54, ujçtą w ramy alegorycznego panegiryku-apelu do Cromwella, w którym sprawozdanie ustępuje miejsca poetyce perswazyjnego exemp/mm, zagrzewającego Lorda Protektora do interwencji w egzystencję niezadowolonego autora. Z drugiej strony, nasycenic estetyzmem jako wyznacznik literackich opracowań Dymitriad również ujawnia swoje ograniczenia, gdyż w wypadku niektórych z utworów uzasadnione wydaje się raczej nówienic o kryterium „estetycznego zamierzenia”" (Locustus Fletchera) lub nawet o „estetyzmie niezamierzonym" (przypadek Neu's of the Present Miseries of Rushia Henrego Breretona).

\section{Okiem kupca, okiem żołnierza}

Wspomniane uproszczenia w postrzeganiu postawy Polaków w Dymitriadach ujawniły się takze w relacjach naocznych świadków Wielkiej Smuty. Stosunkowo najmniej jest to widoczne w najwcześniejszej relacji z I Dymitriady, z jaką zapoznali się Brytyjczycy. Byla to Blondie Tragedie, opis nie będący oryginalnym dziclem Anglika, lecz zaadoptowany przez Williama Russela, jednego z angielskich kupców pracujących dla Kompanii I lolenderskiej. Otrzymal go z rak bezpośredniego świadka wydarzeń, bogatego i wplywowego kupca niderlandzkiego, cudem ocalalego z moskiewskiej rzezi w maju 1606. Russel przetlumaczyl ten list-świadectwo i opublikowal w Londynie w 1607 rokut ${ }^{+}$.

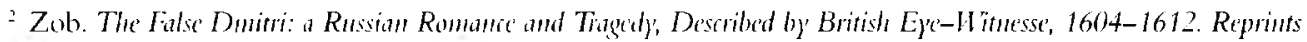
of Comtemporan Repoits....ed. with pret. by S. E. I lowe. London 1918 (wydanic ozdobione portretani z epoki). "Howe przedukowala takze kontrakt slubny Dynita i Maryny (angielski picrwodruk 1625), który potwierdzil stawiane Dymitrowi i Polsce zarzuty. zwhaszeza o instrumentalue traktowanic Rosji jako pola jezuickicj ekspansji (por. ibidem, s. VI). Udostçpnita takze angiclskicj publiczności listy towarzyszalce relacjom angielsku-rosyjskim tego czasu. Wśród zgromadzonych listów znajdıje się nota dyplomatyczuna skierowana do posta Jakuba I w Rosji, Thomasa Sunitha. z lipa 1605 z informacja o wstapieniu Dy mitra na tron i ofertą kontymuacji dobrych handlowych stosmkiow: Sir Thomas Snith opisal ostatnic miesiące panowania Godunowa w: loyage and Encrtainmemt in Russia, London 1615.

+ Pierwodruk angielski stal się podstawą thumaczeń na inne języki (por. S. Howe, wprowadzenie do Blomdic

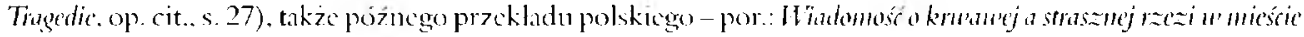


Wyraźne jest tu zróznicowanie oceny Polaków: 11a pozytywną wobec znanych kupcowi osobiście magnatów Rzeczypospolitej i negatywnį w stosunku do Polaków jako ogólu. Jeśli przyjąc tezę Sonii I Iowe, ze Russel byl bezpośrednim adresatem listu Holendra, to z pewnych jego wzmianek wynika, że w tragicznych wydarzeniach w Moskwie I Dymitriady towarzyszył nu brat Anglika. Po wstąpieniu Dymitra na tron obaj nawiązali kontakty z Mniszchem, uzyskując od niego zapowiedź przywilejów'. Zależność ta wskazuje na związki tych kupców ze sprawą polską, co zapewne uwarunkowalo wspomniane wyzej zróżnicowanic oceny Polaków. Nawiązane z Mniszchem więzy spowodowaly, że bogaty I Iolender wypowiadal się o nim z respektem, nazywając ,.swoim Panem”". W opisie uroczystości weselnych widać również ogrommą sympatię kupca dla obojga nowożcńców, zwlaszcza dla Maryny, towarzyszącą mu także później, gdy ze wspólczuciem odmalowuje uczucia zaskoczonej tragicznym obrotem wypadków carycy.

Znacznie ostrzej niż polskich możnowładców ocenial Holender postawę Polaków jako spoleczności będącej stroną w rozcgranym konflikcic ${ }^{7}$. Autor nie ma wątpliwości, że to właśnie alians Dymitra z Polską przyczynil się dojego upadku. Choć zarzuty wobec Polaków jako bezkarnych gwalcicieli, którzy zawłaszczali prawo przystępu do cara, przywoływat on z pewnym nicdowierzaniem i bez przekonania cytował punkty potępienia, ogłoszonego nad prochami Dymitra, ostatecznie nie widział powodı, dla któreggo Opatrzność l3oska miałaby czuwać nad Polakami. I Jolender nie byl calkiem pewien, co myśleć o Dymitrze, nie widzial w 1 im uzurpatora, nie zobaczył zatem w Polakach awanturników osadzających na moskiewskim tronie samozwańca. Z drugiej strony pochodzenie Dymitra nie wydawało mu się tak zasadnicze, gdyż jego zdaniem móglby on utrzymać koronę, gdyby siç nie zblizał z Polakani, lecz „zaadoptowal” do rosyjskich zwyczajów, ozenil z Rosjanką i przede wszystkim odrzucil ządania „morderczych polskich jezuitów”:

I an of opinion, if he had bonc himselfe more mildely, withought medling with the Poles, and matched with some Lady of the comtrey, aphlying him selfe to their humor, thongh he had beene baser then a pund-fed Monke, yet might he have kept the Cromene on his head: but I beliete that the Pope, with his Seminaries, and Jesuites, there a principal canse of his mine, and totall sublersion. For these murderers of Princes u'ould needs have made a Monke, too quickly, and they as suddenhy light within the Bec hiwe. It is pitry that their heads,

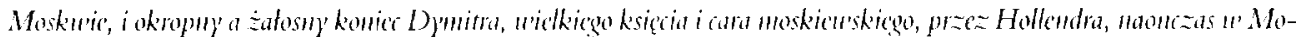

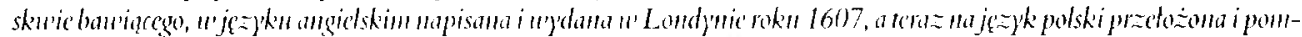

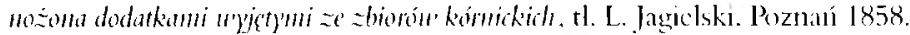

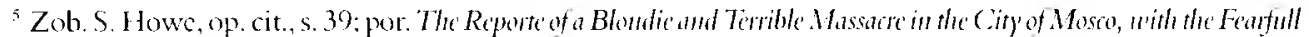
and Tragicall End of Demetrias the Last Duke, Before I Im Raining at this Presemt. At London 1607.

" Por. np.: Bloudic tragedit'..., S. I Iowe, op. cit.. s. 35.

Zob, ibidem, s. 57: I Ioknder uwazal, ze plan uxiçzienia Polaków i wykorzystania ich jako zakladuików do targów o zwrot zagarniçtycl skarbów zostal przez bojarów ukartowany. na długo zaniun Mniszcluwe i świta zjawili siç w Moskwic (por. ibidem. s. 4.3).

"Ibidem, s. 55-58. 
u'ere no better sanen, but the' were transformed, too cummingly in to secular habit: such maskers, never paint themselpes lightly, but in grene'.

Esencją stosunku kupca holenderskiego do Polaków wydaje się jego przckonanie, że wyraża opinię Boga, który podczas moskicwskiej masakry nic pomógł polskiemu wojsku, choć przy lepszcj taktyce mogłoby ono uderzyć znacznie skuteczniej od Rosjan. Zarówno Bóg, jak autor relacji uznali zatem, że Polacy na tę pomoc nie zaslużyli, gdyż nie bylow nich dobra, lecz „równe zlo, jak w Rosjanach" "'. Jako kupiec Iolender rozumiał starania Polaków z otoczenia Dymitra o pozycję i korzyści materialne, potępiał jednak ich niemoralność, prowokowanie niebezpiecznych zamieszek oraz postawę projezuicką. Jego optyka kupca i protestanta w pelıi zgadzala się z perspektywą brytyjskia, utrwalając negatywny obraz Polaków na Wyspach.

Zachowane żohnierskie relacje pochodzą z okresu II 1)ymitriady i szkicują Polaków wylącznie jako okrutnych i bezpardonowych morderców, mściwych, nichonorowych oraz zdradliwych. Kim byli autorzy tych opisów i skąd czerpali swoją wiedzę? W Dymitriadach ujawnit się paradoks najemnego wojska, walczącego dla tego, kto płaci, a nie „za sprawę”, gdyż brytyjskich zolnierzy-świadków Dymitriad znajdujemy po obu stronach barykady. Captain Gilbert's Report to wspomnienia byłego czlonka straży przybocznej Dymitra, który przyłączyl się również do drugiego Samozwańa ". Druga relacja: A Narrative of an Englishmen Sening Against Poland ${ }^{12}$, spisana ręka jednego z zolnierzy z oddziału kapitana Crale'a, ukazuje dramatyczne losy zaciagów dokonanych przez Szwedów w roku 1609.

Kapitan Gilbert pokazıje Polaków jako siłę napędzającą II Dymitriady. Referuje swoje skonfundowanie spotkaniem z drugim Demetriuszem, rzekomo cudownie ocalalym z moskiewskiego pogrom ${ }^{13}$, który byl doskonale zoricntowany w szczególach shużby Anglika dla pierwszego Samozwańca, jednak do dawnego chlebodawcy Gilberta podobny byl „jak dzień do nocy". Kiedy jednak kapitan podziclil się swoimi wątpliwościani na temat tożsamości Eżedymitra z „polskim generalem”, uslyszal, że jest ona bez znaczenia, o ile tylko umożliwi Polakom zemstę na perfidnych i krwawych Rosjanach ${ }^{1+}$. Mimo ze many tu do czynienia z relacja pisaną z pozycji polsko-rosyjskicj strony barykady, Polacy jawią się jako dopust Boży, powodıjacy glód i gwatty, a opis Gilberta oddaje zaledwie prelıdium do kolejucgo aktu dramatu, mianowicie „wkroczenia stutysięcznej armii z królem Zygmuntem na czele, atakującym Moskwç i osiadłym w Smoleńsku"15.

Obie relacje wojskowe przynosza szczegúly taktycznc. Opis autorstwa szeregowca z najemnego oddziału kapitana Crale'a został wręcz zdominowany przez perspektywç wojskową.

\footnotetext{
"Ibidem, s. 60).

"Ibidem. s. 52.

"Dowódcami straży Dymitra poza Francuzem hyli wymienicni z nazwiska w Bloudie' Thugredic'.. Anglik Mathew Kuolson i Szkot: Alhert Fancic (op. cit.. s. 33).

12 S. Howe, op. cit.. s. 151.

$"$ Por. Captain's Gilbert Report, w: S. I Iowe. op. cit. s. 60.

1. Hidem, s. 67.

"Hoidem, s. 68.
} 
Żohnierz nie rozumie polskiej taktyki lub wręcz ja potępia jako okrutną dla ludności cywilnej i przyıosząca niepotrzebne straty. W jego relacjach wiclokrotnic pojawia sic̨ bezwzględność polskich żołnierzy, przykladów okrucieństw, które jednak, jak przyznaje autor, nie dorównuja zachowaniu Kozaków ${ }^{\text {in. }}$.

Anonim z oburzeniem przytacza informacje o podstępnym i niehonorowym działaniu polskiej strony. Jednym z bardziej drastycznych tego przykladów było podstępne zabicie rosyjskich arystokratów. Podczas konwojowania Szujskiego do Polski, zwabicni zostali do polskiego obozu pod pozorem pożegnania cara, następnie zaś zdradziecko wybici. W tej perspektywie staje się zrozumiale, dlaczego upadek ginącej z glodı polskiej załogi na Kremlu anonimowy żołnierz przyjnnuje jako, spektakl sprawiedliwy, choć smutny"1?.

Z relacji żołnierza wyłania się unnysł prosty i nawykły do okropieństw wojny. Jest on przede wszystkim obserwatorem i sprawozdiwca, nic zadaje pytań o plan ogólny, postępując konsekwentnie droga lojahnego najennika, dla którego istnieją nie wrogowie, lecz przeciwnicy. $Z$ drugiej strony wydaje się, ze jego przekonanie o bezwzględności Polaków wpłynęło na decyzję o nieprzechodzeniu ma ich stronę, co ostatecznie uczyniła częśc jego towarzyszy broni.

Widzimy więc jak opinie obu zotnierzy uogólniają oloraz lolaków, czyniąc na przyklad dzialania Lisowczyków tożsamymi z postawą całego polskiego wojska. W relacjach tych występıja po prostu Polacy, jednako okrutni, bezwzględni i podstępni, stwarzając przekonanie, że opisywanc grupy wojskowe byly reprezentatywne dla calego spoleczeństwa Rzeczypospolitej.

\section{W kręgu literackim}

\section{a. „Obcy” — źli sprzymierzeńcy i doradcy}

Jako źli i okrutni przedstawiani byli Polacy równiez w literackich opracowaniach motywów z Dymitriad. Cechy te ujawniały się nie tylko na polu walki, lecz także w relacjach spoleczno-politycznych, w pogardliwym i zaczepnym stosunku do Rosjan oraz złym wpływie 11 a Dymitra. Dwa utwory: A Bricf Historical Relation of the Enpire of Russia oraz Neu's of the Present Miseries of Rushia szczególnie akcentują te whaśnic cechy polskich uczestników Dymitriad.

Falszywa postawa Polaków jako egoistycznyclı i destrukcyjnych pomocników Dymitra uwypuklona została zwlaszcza w pierwszym z tych utworów, gatunkowo oscylującym miçdzy panegirykiem a satyra. W. A Bricf Histerical Relation of the Empire of Rusisa ${ }^{18}$, podpisanej inicjalami „I. F”, Polacy występują przede wszystkim jako falszywi doradcy Dymitra. W niniejszej analizie tekst ten sytuıje siç między relacjami naocznych świadków a tekstami o charakterze literackim, rozpoznajemy tu bowiem czytelne skrzyzowanie sprawozdania, parenetyki

\footnotetext{
"Midom, s. 174.

Ibidem, s. 175.

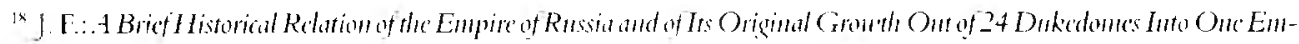

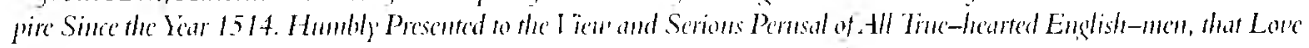

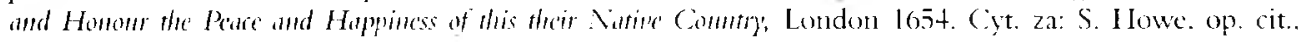
s. $18+-220$.
} 
oraz alegorezy. Ta wydana w Londynie w roku $165+$ ksiązeczka, od listu dedykacyjnego po konkluzję odsłania osobiste pobudki nieznanego autora, utożsamiane przez niego z dobrem publicznym. I listoria rosyjska posłużyła J. F. za instrument do interpretacji zarówno dziejów Anglii, jak wlasnej sytuacji, którą oceniał jako glęboko niesprawiedliwą i wymagającą interwencji Cromwella. Wykorzystanie rosyjskiej kanwy historycznej uzasadniał fakt, że w swej wieloletniej wędrówce po Furopie autor dotarł równiez do Rosji i spędzil tam 22 miesiące podczas oblężenia Kremla, zostając również świadkiem kapitulacji polskiej załogi i". Z partii autobiograficznych tekstu wynika, ze w swoim przekonaniu po powrocie do kraju oddal on znaczne a nigdy nie nagrodzone usługi zwycięskiej rewolucji, zaś „w nagrodę” został niewinnie oskarżony o planowanie zamachu na życie Cromwella. Omawianą "historię Rosji” dyktıją mu wielka gorycz i zal do Lorda Protektora, który dotąd nie zarcagowal na jego apele. Mimo manifestowanego żalı przesyca również tekst elementami panegiryczno-parenetycznymi.

Dla realizacji obu stawianych przez J. F. celów - panegiryku wobec Lorda Protektora oraz krytyki skorumpowanego sądownictwa angielskiego - obraz Polaków odgrywa rolę kluczową. Zamierzenia J. F. sprawiły, że jego „historia” jest powiéscią z tezą. Czasy Godunowa, jako rosyjskiego „lorda protektora”, jawia się w tej opcji jako wiek zloty, w Anglii zainicjowany, lecz zatrzymany przez Cromwella w pól drogi. Zloty wiek na Wyspach zahamowała niesprawiedliwość sądów. Ukazıijạc prawdziwy zloty wick w Rosji, podkreślal konsekwencję Godunowa jako rzecznika „czystej sprawiedliwości”, i niedwuznacznie wskazywal na konieczność podązenia jego śladani i zannicjowania przez Cromwella lustracji doradców i urzędników rzeczypospolitej angielskiej.

Relacja J. F. w wielu miejscach jest bardzo nieścisla. Widoczna jest dbałość o plan całości, a brak zainteresowania dla historycznego szczegółu. Autor traci z oczu proporcje, myli liczby i daty, szkicuje zaledwie scenę, gdyż nie o szczegół historyczny mu chodzi, lecz o zarysowanie „palącej” analogii między Anglią i Rosją.

Konsekwentnie negatywna opinia o Polakach uzasadıia ukazanie oblężenia i kapitulacji Kremla w kategoriach Sądu Bożego. Czym sobie na tenn dopust Boży zashıżyli? Z perspektywy zarysowancj przez autora, śmiertelnym grzechem było zle doradzanie Dymitrowi. Klıczem do interpretacji utworu J. F. staje się opozycja Godunowa i Dymitra, wyłoniona na tle ich stosunku do doradców. Godunow nie ufał zlym doradcom i uczynił Rosję „krajem mlekiem i miodem plynącym", Dymitr zaś, mimo heroicznego ducha, zaprzepaścil swoje możliwości, otoczywszy się złymi doradcami. W tej to zalegoryzowanej perspektywie na arenę opisywancj historii Rosji-Anglii wkraczają Polacy, uosobienie złych doradców Dymitra-Cromwella. J. F. widzi i stawia przed Cromwellem wybór między postawą Godunowa a Dymitra. By uniknąć losu Dymitra i sprowadzić dobrobyt do Anglii, powinien on odrzucić falszywych doradców (którzy oskarżyli J. F. - losy osobiste utożsamiane są tu z dobrem ogółı) ${ }^{2 i 1}$. Jak dziś

\footnotetext{
1" Zob. s. 187; we wstępic Howe oblicza za autorem. że spędził on 22 miesiące z "Polakami w Moskwie” (por. s. 184).

") Por zwlaszcza konkluzję. \$. 219-220).
} 
Lord Protektor, tak niegdyś Dymitr zostawił calą politykę w rękach otoczenia i pozwolił się całkowicie wieść swemu sekretarzowi, panu Buczyńskiemu oraz kilku innym polskim pochlebcom i pasożytom ${ }^{21}$. Car zaniedbal również odpowiedzi na petycje niezadowolonych obywateli, czego whaśnie domagał się zawiedziony autor od Lorda Protektora. Dokonana przez niezadowolonego angielskiego obywatelit analiza ukazuje Polaków jako zgubę Dymitra, w alegorycznyın planie obrazującyclı wspólczesne J. F. otoczenie Cromwella.

W sentymentalno-heroicznej opowieści I Ienrego Breretona Neu's of the Present Miseries of Rushia (1614), Polacy to nie tylko źli doradcy, to również błędnie wybrani sojusznicy polityczni²- Brereton z dużą dbalością o efekty teatralne ukazal 1)ymitriady jako dzieje niewłaściwego wyboru przez Dymitra oficjalnego partnera politycznego. Autor nie przyjąl do wiadomości informacji, jakie o pochodzeniu, zachowaniu i sytuacji Samozwańców rozpropagowali inni pisarze. W jego opowieści, zrodzoncj z tezy, że jeszcze nigdy historia nie była tak „fatalna" dla zadnego władcy ani kraju ${ }^{23}$, przedstawione sa losy Dymitra - jedynego prawowitcgo potomka Iwana Groźnego, whadcy dobrego, lecz obciążonego cechami ojca-tyrana $^{2+}$, który szukając politycznego sprzymierzeńca poza krajem, popetnił błąd, zakochując się w Polce (spokrewnionej z polskim królem, pięknej „Księżnej Marynie”), a następnic otoczył się Polakani, czym zrazil sobie od dawna zazdrosnych poddanych, zwlaszcza konkurenta Szujskiego.

Akcentując sentymentahne wątki tej historii, Brereton poświçca wiele uwagi uczuciu Dymitra i Maryny, typowej pary sentynentalnej. Autor rozsnuwa przed oczyma czytehina ich historię miłosna.jej początek i przebieg. Zgodnie z sentymentalną tradycją zaczątkiem uczucia stal sił̨̧ portret Maryny, który poruszyl serce Dymitra i sklonił go do podjęcia negocjacji politycznych i matrymonialnych z polskim królem. Po ich zakoniczeniu wyruszył w podróż do Polski, skąd wrócil bez reszty i z wzajemnością zakochany. Miłość do Maryny odebrała Dymitrowi zdolność do oceny politycznej wagri aliansu z lolskę, która okazala siç wyborem zlym i tragicznym w skutkach. Miłość i cechy rodowe thumaczą jednak w oczach narratora działanie jego bohatera, którego nie tylko nie krytykowal, ale stał zawsze po jego stronie, okazıjąc sympatię jako ,prawowitemu whadcy Moskwy”. Nie szczędzil natomiast krytycznych uwag podstępnemu Szujskiennu oraz otaczającym go Polakom - bezkarıym prześladowcom Rosjan. 1)wie informacje o Polakach przywołuje autor jako bezsprzeczne: ze jest to naród bardzo dumny, a względy okazane mu przez Dymitra nicbezpieczuic tę dumę podwoily ${ }^{25}$, oraz ż Polacy budzili powszechny strach Rosjan przed zbrojna konfrontacja, jako duzo lepsi od nich

\footnotetext{
II Ilidem. S. 2011 .

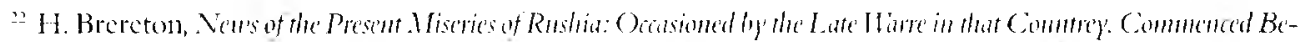

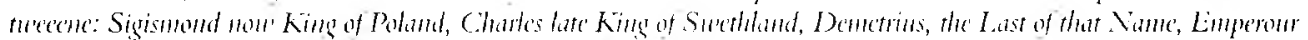

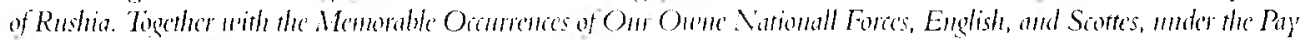
of the now King of Sucthland. London 101t, cyt za: S. Howe.up. cit., s. (6-150).

2 Uidem, s. 71 .

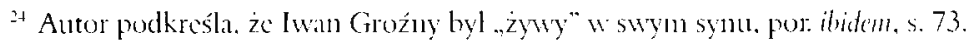

25 Por. ibidem, s, 80).
} 
żolnierze ${ }^{2 n}$. Listę grzechów Polaków zamyka zdrada, gdyż okazali się nielojalni wobec Dymitra w czasie odpowiadającym wydarzeniom II Dymitriady.

Jak nie przyjmowat Brereton do wiadomości bardzo niepewnego pochodzenia Dymitra, tak i późnicj odrzucil informację o jego śmierci, uznając ją za mistyfikację Szujskiego. Śmierć Dymitra w zamachu Szujskiego nie pasowala do sentymentalnej wizji Breretona. Atak na palac zastal Marynę i Dymitra w uścisku miłości, gotowych umrzeć razem, uciekających ręka w rękę, niczym „Eneasz z plonącej Troi” ${ }^{27}$. W dlugich, petnych wspólczucia zdaniach opisywał ucieczkę kochanków, walczących z nurtami Wołgi, postrzegat ich jako „,wielkich ludzi w malej tódce" ${ }^{28}$, dzięki miłości pokonujących życiowe przeszkody. W podobnie heroiczno-sentymentalnym stylu przedstawił Brereton II Dymitriadę, ukazując ja jako starania prawowitego władcy o odzyskanic tronu w oparciu o sity Polski. Do Rzeczypospolitej dotarł Dymitr z Maryną w przebraniu, i tam się też na zawsze rozstali, gdy stanął na czele armii wyruszającej na podbój Moskwy. Autor poświęcil wiele miejsca na ukazanie dramatu wêwnętrznego Dymitra jako władcy zmuszonego patrzé na okrucieństwa wojny zadawane jego własnym poddanym, okrucieństwa, których chciałby uniknąć, a których pragnęli Polacy, będący nie tylko żądni krwi, mordu i tyranii oraz „prosty'tuujący” wszystko na swej drodze (jak to określa Brereton), ale równiez zdradzieccy, gdyz ostatecznie opuścili Dymitra.

Ukazując śmierć zdradzonego przez Polaków cara, Brereton po raz kolejny teatralıie zwraca się do widowni-czytelników, prosząc o wspólczucie dla wielkich protagonistów tej tragedii, zwłaszcza Dymitra „Iwanowicza”, za którego los największą winę ponosili „niegodni obcy", Polacy.

\section{b. „Obcy ingerujący w wewnętrzne sprawy innego państwa}

Część utworów atıgielskich tego okresu akcentowala jeszcze inny składnik tej „obcości” Polaków - obcą siłę polityczną i religijną ingerująca w sprawy wewnętrzne państwa moskiewskiego. Ujęcie to było szczególnie bliskie brytyjskim autorom, gdyż taki obraz Polski pozwalal na budowanie między Rosją a Wyspani Brytyjskimi analogii opartej na stylistyce permanentnego zagrożenia.

Polska reprezentowała takie zagrozenie przede wszystkim jako państwo katolickie, a tym samyın narzędzie w rękach makiawelicznych jezuitów. W taki sposób obrazuje udział Polaków w Dymitriadach poemat antyjezuicki Phineasa Fletchera ${ }^{29}$ Locustus or Apollyonists ${ }^{30}$, wydany w 1627 roku. Ostrze krytyki Fletchera kierowało się przeciw jezuitom jako wysłanni-

\footnotetext{
2o Por. ibidem, s.87.

27 Por. ibidem, s. 9)-91.

${ }^{2}$ Ibidall. s. 92.

${ }^{24}$ Fletcler. poeta i ksiądz, byl synem (iila Fletchera. angielskicgopocty i dyplomaty, czlonka Parlamentu, kitóry w 1588 roku byl ambasadorem Angli w Rosji. autora traktatu Of the Russc Common Ilealth. Or; Mant of Goue' mencht of the Russc Emperour (Commonly Called the Emperour of Moskonia) with the Mamers, and Fashions of the People of that Countrey, London (1591).

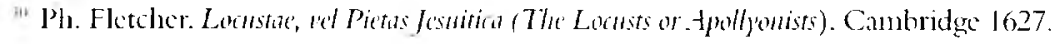


kom Rzymu i Hiszpanii, przed którymi Opatrzność Boska dotychczas chronila tę ..malą wyspę", jak nazywa Anglię. Poeta skupia się zwłaszcza na udaremnionym zamachu fanatycznych katolików na króla Jakuba I, podjętym w 1605 roku i znanym pod nazwa „spisku prochowego". Jak pisze Cecily V. Wedgwood, spisek ten wplynąl na ukształtowanie się w Anglii niemal histerycznej wiary w machinacje jezuitów jako narzędzi znienawidzonego papizmu" ${ }^{31}$. Zbieżność dat spisku prochowego z wydarzeniami rosyjskimi pozwoliła Fletcherowi na zbudowanie analogii ${ }^{32}$ i potraktowanie Dymitriad jako kolejnego przykladı Boskiej Opieki chroniącej przed „morderczymi” jezuitami. Tym razem Opatrzność zdemaskowala machinacje jezuitów także w Rosji, chroniąc ten kraj przed papizmem narzucanym tann przez wykreowancgo przez polskich jezuitów oszusta.

W pieśni IIl tego poematu dzialanie Polaków zostało utożamione z planami jezuitów, piekielnych zastępów żądnych krwi i wladzy muichów, gotowych na wszystko, by „osadzić” papizm w Rosji. W perspektywie Fletchera cel ten zostal przedstawiony jednoznacznie:

\section{8.}

But none so fits the Polish Jesuite,

As Russia's dhange $[\ldots]$

Straines all his tisits, and friends; the' w'orke', the' plod

With double pole the Russian necks to load;

To cronene the Polish Prince their King, the Pope their God.

W tym ıjęciu Dymitr stal siç jedynie pionkiem w jezuickicj grze o panowanie nad światem, marionetką od początkı wyuczoną swej roli w „Dymitriadowej maskaradzic”. Wylącznym ich cclem była konwersja całej Rosji na katolicyzm:

\section{1.}

With mimicke skill, the'y trayne a caged beast,

And tead him play' a royall $L$, 'ons part:

Then in the Lyons hide, and titles dre'st

They bring him forth: he master in his ant,

Soone wimes the Inlgar Russe, who hopes for rest

In change; and if not case, yet lesser stmort:

All humt that monster, he soonc mets his pride

In abject feare; and life himselfe envide:

So nelp't a Fox, a IVolfe he liv'd, and asse he dide.

Towarzyszący temu fragmentowi autorski komentarz przedstawia przypadek Dymitrajako całkowicie zaaranżowany przez polskich jezuitów, nie zaś jedynie wykorzystany przez nich

\footnotetext{
$"$ Por. C. V. Wedgwood. Poctry and Politics moler the Stmats. C.ambridge 1960. s. $18-19$.

"Por ihidem. Autorka zastanawia siç. jak czlowick o takicjwiedzy i inteligencji nógl ulec nagonce na jezuntów. stad argumcntacyjuy ton w analizic podjçtego przez Flectehera tematu Dymitra.
} 
na tle szerszych działań politycznych, narodowych i osobistych ${ }^{33}$. Natomiast adnotacja na stronie 63 poematu wyjaśnia drastyczną zmianç w zachowaniu Dymitra, który stal siç tyranem, gdyż ujawnił się w nim obcy - jezuicki i polski - pierwiastek, w pełni uzasadniający jego zabójstwo.

Zarzut religijnej ingerencji Polski w sprawy moskicwskic wzmacniany był przez polityczny wymiar tego aktu. W takicj optyce pojawiają siç Polacy jako bohaterowie antyjakobickiej tragedii sentymentalncj Mary Pix ${ }^{3+}$ The Czar of Muscon'), wystawionej w 1701 roku w Lincoln's Inn Fields ${ }^{35}$.

Ta historyczna tragedia, przesycona elementami sentymentalnymi, erotycznymi i silnym patosem, kreuje ciekawe, silne i nieugięte bohaterki kobiece (Maryna i Zarianna), jednak z perspektywy prologu może być też interpretowana jako utwór okolicznościowy, wprowadzający optykę porównawczą Londynu z Moskwą.

Okolicznościowy kontekst sztuki Pix, istotny ze wzğlędu na jej interpretację wątków polskich, wyznaczyla nowa fala jakobityzmu i antyjakobityzmu, która przeszła w tym okresie przez Wyspy Brytyjskie. Katolicki król Jakub II, zdetronizowany w wyniku „Chwalebnej Rewolucji” i przebywający na wygnanin we Francji, zmarł właśnie w roku 1701. Po jego śmierci Londyn „zasypany” zostal drukami okolicznościowymi, zwlaszcza elegiami żatobnymi, poruszającymi ponownie kwestię praw do sukcesji tronu angielskiego. Traktowano tam Jakuba II jako jedynego prawowitego władcę z dynastii Stuartów. Zwolemnicy rządzącej aktualnie orańskiej linii Stuartów i republikanie odpowiedzieli atakiem satyrycznym, kierując ostrze przeciw legendarnym i budzącym grozę ,tyrańskim” skłonnościom Jakuba II, możliwym do ujawnienia u kolejnego pretendenta do tromu z jego linii, czyli Karola Edwarda Stuarta. Tak też może zostać zinterpretowany dramat Pix, poświęcony jedynie pierwszej Dymitriadzie (1605-1606), chodź wykorzystujący równiez w scenicznym skrócie wybrane wydarzenia z kolejnej (1607-1609). Prolog sztuki jasno sugeruje analogię Moskwa-Londyn:

But here the Scenc shou'd all its n'ants supply',

For Wit is not the grouth of Muscoery:

Tho', faith of late so flat your tast is grou'n,

That Mosco may refine upon this Tou'n $[\ldots]^{36}$.

"Pretendent" zostal po śmierci ojca oficjalnic uznany przez Ludwika XVI za prawowitego króla Angliı i proklannowany Jakubem III. Stanowil on w Anglii staly powód politycznego i religijnego napięcia, niósł bowiem zagrożenic inwazją z pomocą sił francuskich, co do-

\footnotetext{
${ }^{33}$ Por. ibidem. komentarz na s. 62.

"4 Mary Pix, dośc znana pisarka angiclska czasów późncj Restantacji, lączona byla w .trójcy” z innymi autorkamii: Belavier Manley i Catharine Trotter. Wszystkic trzy nazywanc byly (czasami nic bez pewnego przekasu) women wits. Wyjaśnicnic tej nazwy oraz jej konsckwencje zob.: C. C.lark. Three tugnstan Ilomen Playmights, "American University Studies" series t: English hanghase and literature, vol. 40 (1986).

"Zob. A. Nicoll, A Hisrory of English Drama, 1660-1900. vol. 2. Cambridge 1927. s. 97.

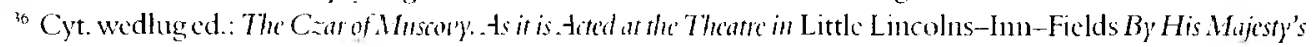
Serrants, London 1701. Sztuka ukazala siç bez mazuiska autorki.
} 
prowadziloby do ponowncj wojny o sukcesję Inspirowane tym zagrozeniem antykatoli cyzm $^{37}$ onaz antyjakobityzm ${ }^{3 \mathrm{~B}}$ Pix, stanowily stały wyznacznik jej twórczości już od pierwszej napisanej przez nią tragedii (Ibrahim, 1696).

Losy Dymitra Samozwańca w sztuce Pix zostaly tak uksztaltowanc, by ukazać niechybny los niepopularnych pretendentów do tronu wykazujących skłonności tyrańskie. W perspektywie pretensji zdetronizowanych Stuartów do angielskiego tronu, otrzymujemy obraz tyrana pokonanego (zarówno na plaszczyźnic politycznej, religijnej jak prywatnej), a wolności odzyskanyclı.

Od pierwszych scen dramatu polscy bohaterowie odgrywają istotną rolç zarówno w akcji tragedii, jak w ksztaltowaniu jej ideologicznej i sentymentalnej wymowy. Sztuka zaczyna się sceną ślubu nowcj carskicj pary. W orszaku ślubnym otaczającym nowożenców znajdıje się ojciec nowej carycy: Manzeck (wojewoda sandomierski, Jerzy Mniszech), dzialający tu z ramienia polskiego króla i dysponujący stacjonującymi w poblizu choragwiami, wydatnie wzmacuiającymi pozycję Dymitra.

Obok Mniszcha w orszaku ślubnym Dymitra i Maryny kroczy kilku niewymienionych z imicnia polskich magnatów i dam. Ich obecność ma podkreślić rolę obcego, polskiego pierwiastka w przeprowadzonej intronizacji. jego wrogi, interesowny i niezgodny z rosyjskimi tradycjami charakter. W przebraniu muicha-pątnika przybywa tam równiez inmy Polak. Aleksander, syn księcia Wiśniowieckiegro (postać fikcyjna), były konkurent do ręki Maryny, który przeżywa osobisty dramat, widząc, że inny mężczyzna pojąl za żonę jego ukochaną.

Reprezentanta polskicj polityki w tym utworze, wojewodę Mniszcha, cechuje cynizm i kierowanie się whasnym interesem, zarówno na płaszczyźnie osobistej, jak politycznej. Juź w pierwszych scenach dramatu staje się jasıe, ze malzenistwo córki z Samozwańcem to jego dzielo, zaaranżowane, by czerpać korzyści z jej pozycji jako carycy. Z wypowied zi Maryny dowiadıjemy się, że nienawidzi Dymitra. lecz nienawidzi też Aleksandra Wiśniowieckiego, który zlamal jej serce. Pix czyni namiętność i uczucia motywem dzialania bohaterów tej historii. Z okazji wielkiego dnia l)ynitr oglasza anmestię. Zueski (książę Wasyl Szujski) uznaje jego władzę i oddaje mu bold, obawiając się o zycie swej ukochanej Zarrianny (Kseni), córki Godunowa, którą ukrył w klasztorze, a która dziçki annestii może zyskać szansẹ ocalenia. Początkowo Zueski uczestniczyl więc waranżowanym przez nowego cara spektaklı, jednak gdy Dymitr, którego „apetyt wzróst” wraz z osiągnięciem tronu, zapalal do Zarianny gwaltowna

\footnotetext{
${ }^{7}$ O antykatolicyznuie jako tendencji w dranatach Pix zob.: M. Rubik, English Dramatists, Early Llomen Dramatists $1.500-1800$, London 1998. s. 88.

${ }^{38}$ Antyjakubickie nastawienic P’ix pokazıjo jej nienawiść do wszelkicj tyranii, którą najezşścicj przedstawia w dwu wydaniach - seksualnym i politycznym. Mozna to dostrzec juz od pierwszej jej tragedii lhralim. w kórej tyrania polityczna idąca w parze z gwaltem na kobiccic wiedzic do zguby tureckiego whadece. Szerzej o tyn:

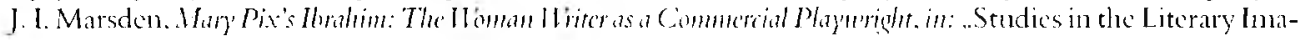
gination" 1999. Nr 10/1, s. 6.
} 
namiçtnością ${ }^{3 \prime \prime}$, zawiązał przeciw niemu spisek. W kręgu uczuć tej piątki: Zarianny, Maryny, Zueskiego, Aleksandra i Dymitra, rozegra się skomplikowana intryga osnuta na kanwie I Dymitriady, o wymowie antykatolickicj, antyjakobickicj i feministycznej.

Zuteski jest najbliższym żyącym kandydatem do tronı z dynastii Rurykowiczów, uznanym i kolejnym po Dymitrze, gdyby ten żyl. W sztuce Pix zagadnienic praw do objęcia wadzy powraca wielokrotnie. Rządy Godunowa uzyskuja pozytywną ocenę - choć uzurpator, byl jednak miłośnikiem wolności i w opinii bojarów oraz ..ludu" prawdziwym ojcem moskiewskiego narodu. Dlatego szybko zaczynaja go załować, tym silniej, im bardziej ujawnia siç tyrania Dymitra w sferze polityczncj, religijnej i moralnej. Moralna i polityczna legitymizacja kandydata do tronu lączy się z zagadnicniem praw krwi, które jednak ustąpić muszą przed cechami prawdziwego wladcy, przede wszystkin czlowieka panstwa i narodı, dbalego o swych obywateli, zdeterminowanego w podjętej funkcji, a dopiero na konicu skupionego na osobistym szczęściu. Dlatego w interpretacji Pix nie sam fakt uzurpacji przekreśla rządy Dymitra, lecz coraz gwattowniej ıjawniane tyrańskic skłomności cara. Grzechem Dymitra staje się tu dązenie do zniewolenia rosyjskiego ludu, pozbawianie go dawnych swobód. Grzechem drugim jest ingerencja w sprawy religii pod wplywem obcych, Polaków - tyrania katolicyzmu wobec rosyjskiego ludu, ,nienawidzącego Rzymu bardziej od śmierci”, która stanie się jednym z kamieni milowych na drodze do jego kaźni. Po trzecic, grzechem Dymitra jest myślenie wylącznie o sobie i wlasnej przyjemmości, holdowanie zwierzęcym chuciom i gotowość oddania władzy za powolność Zarianny. Taka postawa w ocenie czytelnika i widza kompromituje go jako rządzącego.

Konsekwencją tych żądz — zrazu tłumionych, lecz wybuchających coraz silniej, stato się odkładanic nocy poślubnej z Maryną, a w końcu uwięzicnic jej i zażądanie pod karą śmierci rezygnacji z tytułu carycy na rzecz godniejszej rywalki. Odmowa Mniszchówny umotywowana jest podwójnie. Bohaterka, wychodząc za wstrętnego jej Dymitra, poddała się woli ojca, ale teraz jako jego zona czuła się już związana koniecznością dbania o honor wlasny i swej rodziny. Druga obok honoru motywacja Mniszchówny to dązenie do samodestrukcji; wyzywa los, by dopełnił jej dramatı, gdyż związała się ze znienawidzonym Dymitrem na życzenie ojca i bez nadzici na spełnienie swej miłości do Aleksandra Wiśniowieckiego. Decyzja ta została podstępem wymuszona przez chciwego chwały i dóbr wojewodę sandomierskiego. Początkowo przychylny milości Wiśniowieckicgo i Maryny, gdy na horyzoncie pojawil się Dymitr, uznał go za bardzicj obiecującą partiç i postanowił poprzez to małzeństwo osiagnaçć królewskie korzyści. Skorzystał więc z dlugicj nieobecności kochanka córki, który udal się z poselstwem na dwór cesarza nicmieckiego. Manzeck (Mniszech) sfalszowal list od ojca Alcksandra, księcia Wiśniowieckiego, zawiadamiający o rzekomym ślubie syna z niemiecką damą. Straciwszy nadzicję na osobiste szczçścic. Maryna zgodziła się przyjąć narzucane jej przez ojca jarzmo małżeństwa ze znienawidzonyn i fizycznie jej wstrętnym Dymitrem. Pojednanie

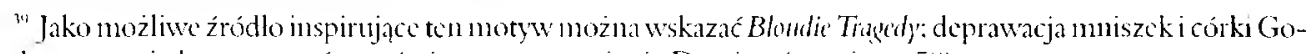
dunowa to jeden z zarzutów pośmicrtnego potẹpicnia Dymitra (op. cit.. s. 58). 
z Aleksandrem - przybylym zbyt późno, by caly dramat powstrzymać - niewiele juz moglo zmienić w jej stosunku do życia, utwierdzając ją tylko w poczuciu, że los ją zawiódl odbicrając szansę na spełnioną niłość. Jednak honor i poddanie ojcu okazaly się drogą hańby. l) latego wlaściwie pragnąc śmierci i drastycznego koníca swej drogi, uparcie odmawia zrzeczenia się znienawidzonego tytulu carycy na rzecz Zarianny, której w istocie go życzy.

Oto następny dylemat komplikujący sytuację Maryny Mniszchówny w sztuce The Czar of Musco' ' - jest to bohaterka nosząca na sobie piętno tragizmu w najbardziej klasycznej formies. Nie kocha męża-cara, a mimo to chce i nussi mu byé postuszna. Chce nu być posłuszna, ale zarazem z uwagi na honor whasny i ojca, nie może ulec żądaniu rezygnacji z tytuhu carycy, który prawnie nabyla, a niczym nic zawiniła, by go utracić. Zatem inaczej ulegnie jego żądaniu, umrze w akcie posłuszeństwa, nie mogąc w inny sposób przeciąć łączących ich więzów, narzuconych jej i nienawistnych.

Równie dramatycznie, lecz bardziej jednoznacznie układają się losy Zarianny. Odmowa ślubu z 1)ymitrem, jej konsekwentne wyznawanie milości dla Zueskiego oraz potajemne z nim zaślubiny spowodowały, że zazdrosny (także o wplywy polityczne) Dymitr postanawia pozbyć się rywala i skazuje go na śmierć. Jednak zautany general Bosman (Basmanow) zdradza i zawiadamia cara o wykonaniu wyroku. w rzeczywistości ukrywając Zueskiego-Szujskiego do czasu wybuchu powstania.

Wystappieniem przeciw Marynie Mniszchównie Sannozwaniec uczynil sobie przeciwnika z jej ojca, swego niedawnego protektora. Mniszchówna w kłótniach z żądającym zwrotu tytułu Demetriuszem bezlitośnie posługiwata się imicnicm ojca i groźbą zemsty. W sztuce picrwotnie potwierdza się zla sława historycznego Mniszcha - jego zachłanność dóbr i chwały, dla których uie wahal się poświęcić szczęścia cótki i zaoferować jej rę̧kę podejrzanenu pretendentowi do rosyjskiego tronu. W obliczu ostatecznych dowodów uzurpacji Dymitra, Muiszech przyznaje, że mial co do takich korzeni sprawy pewne podejrzenia, co nie przeszkodziło mu skorzystać z nadarzającej siç okazji i wydać cókę̧ za Dymitra - wbrew jej woli i dokonawszy falszerstwa - a potem żądać wręcz, żchy udawala, że jest szczçśliwa i zaszczycona.

Wraz z rozwojem akcji dramatu obserwujemy jednak przemianę tego czamego charakteru, który ocknie się z onanienia nadzicja wielkiej chwały rodu i uświadoni sobie haniebność popełnionych czynów. Początkowo cierpi przede wszystkin jego zawiedziona duma. Dowicdziawszy się, że Marynę spotyka ze strony Dymitra afiont, reaguje groźbą ${ }^{+1}$. Jeduak gdy uświadomi sobic zagrożenie dla życia Maryny, urażona duma i wstyd, choć nadal obecne, ustępują miejsca refleksji nad losem zgotowanym wlasnemu dziecku i gwaltownej skrusze ${ }^{+1}$, okazancj również wobec Aleksandra.

Od tego momentu Wojewoda - reprezentujący pierwotnie obą ingerencję i wroga, katolicką siłę - sprzymierza się z obrońcami „dawnej” moskiewskiej wolności i staje po stronic jedynego prawowitego pretendenta do tronu rosyjskiego - Zneskiego, w którego interesic,

\footnotetext{
40 Por akt I, sccia I. w. 64-76.
}

+1 Zob. akt I, sconta II, w: $1-5$. 
zarówno osobistym, jak i politycznym równicż leży pokonanie I ymitra. Staje się chętnym, ufnym i sprawnym koalicjantem. Zbiera swe wojsko i oddaje je pod komendę Aleksandra oraz Bosmana.

O takim uksztaltowaniu postaci wojewody sandomierskiego zdecydowaly dwa czynniki: sentymentalne wątki tragedii oraz wymowa jej zakończenia. Sentymentalna milość jako harmonia dusz i serc cechuje dwie główne pary bohaterów, w których życie zaingerowal tyran: Aleksandra i Marynę oraz Zueskiego z Zarianną. Los zlączył Marynę i Zariannę dzielące carską niewolę, zaś Aleksander i Zueski ramię w ramię wywalczyli ich wolność. Wymowa tragedii jest wiçc optymistycz11a - upadek tyrana to gwarancja powrotu zlotego wieku. Pix wykorzystuje w sztuce niektóre wątki z drugiej Dynnitriady, ale w jej dramacie brak miejsca na kontynuację konfliktı, który po zabójstwie Dymitra miał jeszcze kilka odsłon. Dramatopisarka pokazuje przezwyciężenie go, gdy przeciw tyranowi zjednoczą się wszyscy, i swoi, i obcy. Dlatego harmonia reprezentantów obu narodów, które przed chwila jeszcze traktowały się wrogo i niechętnie, jest koniecznym składnikiem historiozoficznej oceny tyranii i moralncj kwalifikacji wladcy, jaką proponowała swej brytyjskiej publiczności Mary Pix. Braterstwo broni i wspólne dązenia wymagaly ustanowienia hamonijnych relacji politycznych, natomiast feministyczne przesłanie sztuki wymagało zwycięstwa niezłomnych i niepoddających się męskiej tyranii kobict.

Miejsce historycznych Polaków częściowo zajęli w tej tragedii Kozacy, przedstawieni zgodnie ze stereotypowym, negatywnym obrazem jako dzicy i krwiozerczy wojownicy, drogo sprzedający swoje życic. To z nich, a nie z. Polaków składa się u Pix trzon przybocznej straży Dymitra, którego najblizssym atamanem był Carclos, jego zly duch, zachęcający cara do dzialań gwaltownych i okrutnych. Kozacy zdają się doskonale odpowiadać gustom i możliwościom moralnym Dyınitra - stanowią jego miarę, jego dopełnienie. Dynamika przemian Dymitra zbliża go do tego bicguna egzystencji, który można by określić jako „kozactwo i barbarzyństwo". Dlatego Carclos, gdy już nicmal wszystko stracone, doskonale rozumie i podziela stan emocjonalny Dymitra, który tak naprawdẹ nie załuje utraconej władzy, a jedynie faktu, że nie zniewolil Zarianny i musi ją zostawić okrzykiwanemu właśnie carem Zueskiemu. Obaj do ostatnicgo tchnicnia próbują zaspokoić swe żądze erotyczne oraz pragnienie zemsty. Jeden z nich pragnie znieprawić carównę, prawdziwą królewnę - Zariannę, drugi dostaje od swego pana w darze .. Księżniczkę Północnych Ziem” i carycę, Marynę Mniszchównę. Kształt tego ostatniego wątku mógl zostać zainspirowany historycznymi faktami III Dymitriady, związkiem Maryny z kozackim atamanem. Jednak w sztuce Pix taka wizja jest dla Mniszchówny gorsza niż śmieré.

Zastąpienie Polaków Kozakani jest równicż kluczowe w innym motywie sztuki Pix. To oni, a nie Polacy (jak bylo naprawdę) stanowią tu trzon gwardii przyboczncj cara i zostają zmasakrowani, gdy dojrzewa spisek Szujskiego. W tragedii Czar of Muscon'y' nawet negatywnych polskich bolnaterów od Kozaków dzicli ogromny kulturowy dystans. Jako wrogowie tyranii i sprzymierzeńcy obrońców rosyjskicj wolności, mimo początkowej krytyki, zostają tu sportretowani najlagodnicj spośród wszystkich analizowanych ıtworów. 
Pośmierci Samozwańca nic już nie stało na drodze Zueskiego do tronu, na k tóry wstapił wraz z carówną Zarianną, przywracając Rosji utracony złoty wiek. Małzeństwem zakoníczyła się równiez milość Aleksandra Wiśniowieckiego i Maryny Mniszchówny. Relacje między Polską a Rosją wydają się kwitnąć, pokój i harmonia symbolizowana przez wolność ogarniają wewnętrzne i zewnętrzne relacje moskiewskiego państwa. W myśl optymistycznej wizji Pix, wspótdziałanie polskich i rosyjskich przeciwników tyranii zakończylo się petnym sukcesem.

W brytyjskich opisach obrazu Polski i Polaków w Dymitriadach akcenty rozkładaly sic̨ w sposób zróżnicowany. Rola odegrana przez Rzeezpospolitą w moskiewskich wypadkach, z reguly spotykała siç z krytyką i widziana była z perspektywy protestanckiej i ekonomicznej, chó nie brakowało również refleksji egzystencjalnyclı. Z reguły autorzy wybierali jakiś aspekt obecności Polski w Dynnitriadach — polityczny, religijny lub morahy, i wokól niego budowali swoje krytyczne wywody.

Odległość gcograficzna sprawila, ze Polacy traktowani byli (i przedstawiani czytelnikom) niemal jako, ,homogeniczna” jedność, a więc równi i zasługgujący na zbiorczą opinię, gdyż byli jednako dumni. okrutıi, podobnie notywowani. Widoczny jest brak starań autorów o zrozumienie zlożoności ich udziału w etapach wielofalowych przecież działań, brak krytycznej refleksji o reprezentatywności postawy zamieszanych w wypadki moskiewskie Polaków dla oggółu polskicj szlachty i opinii dominującej w państwie. Od początku do końca rola polskich uczestnikow interpretowana jest jako reprezentatywna dla calej Rzeczypospolitej, jako jej oficjalna interwencja polityczna i religijna. Do odległości geograficznej dołączyła się temporalna, inspirując retrospekcyjny ogląd Dymitriad, przypisujący na przykład pierwszej Dymitriadzie okrucieństwa popetniane przez Lisowczyków w drugiej i po jej zakoníczeniu. Zarówno utwory sympatyzujące z Samozwańcem, jak go potępiające, w Polakach widzialy najczęściej przyczyılę upadku Dymitra.

Udział Polaków w Dymitriadach pojawil się w kilku tekstach brytyjskich jako motyw literacki, unożliwiający analizę wewnę̧trznej i zewnętrznej sytuacji Anglii, zarówno z perspektywy prywatnej,jak publicznej. Tendencja ta pojawia siç po raz pierwszy w okresic protektoratu Cromwella, by najpetniej wyrazić się w utworach antyjezuickich, a od ..Chwalebnej Rewolucji" i antyjakobickich. Swobodne traktowanic historii służylo ksztaltowaniu różnych motywów literackich: Polska jako alegoria papistowskiej, zagrazającej jakobicką inwazją Francji, Polacy jako źli doradcy, niewierni sprzymierzeńcy lub okrutni i nicluonorowi zolnierze, to tylko niektóre z nich.

Najbardziej złozoną funkcję wyznaczyla polskim bohaterom Mary Pix. W swej tragedii łączącej treści antyjakobickic i antykatolickie z feministycznymi ukizała przemianę lolaków $z$ alegorycznej reprezentacji katolickiej Francji w obrońców wolności przed osadzonynn na tronic tyranem, gdyż walka z tyranią w kiżdej sferze życia byla najważniejszym celem i ape- 
lem tej autorki. W tym najpóźniejszym literackim ujęciı Polacy jako, ,nawróceni” przeciwnicy tyranii - choć w innych utworach nierzadko portretowani jako barbarzyńscy na równi z Kozakami, zyskali ocenę duzo bardziej umiarkowanych i cywilizowanych.

Niemal wszystkie przytoczone przykłady brytyjskich opinii na temat Polaków w 1)ymitriadach potwierdzają uzyteczność tego tematu jako kanwy szerszej refleksji politycznej, religijncj i egzystencjalnej, często dotyczącej przede wszystkim lıb nawet wyłącznie sytuacji i kultury Wyspiarzy. 